\title{
ANALIZA UNUI LOT DE MATERIALE DESTINAT TORSULUI ŞI ȚESUTULUI, APARȚINÂND EPOCII BRONZULUI, DESCOPERIT LA HuREZANi, COM. HuREZANI, JUD. GORJ
}

OANA GHEORGHE, PETRE COLTEANU

\begin{abstract}
REZUMAT:
În urma cercetărilor arheologice preventive desfășurate pe parcursul anului 2019, în comuna Hurezani, județul Gorj, a fost identificat un sit arheologic aparținând epocii bronzului. Din varietatea pieselor arheologice descoperite, în cadrul acestei lucrări ne propunem să prezentăm un lot de materiale destinat prelucrării fibrelor vegetale și animale prin înregistrarea datelor tehnice într-un catalog și o analiză a acestor date în funcție de tipul de descoperire și de context.
\end{abstract}

\section{AbSTRACT: ANALYSIS OF SOME ARTEFACTS USED IN SPINNING AND WEAVING FIBRES IN THE BRONZE Age, discovered at Hurezanj, Gorj County}

Following contractual archaeological research carried out during 2019 at Hurezani, Gorj County, we identified an archaeological settlement belonging to the Bronze Age. From the variety of artefacts discovered there, within this paper we aim to present and analyse the tools used in the production of textiles, such as spindle-whorls or loomwights, by registering their technical specifications in a catalogue of archaeological discoveries.

CUVINTE CHEIE: Hurezani, județul Gorj, epoca bronzului, fusaiole, greutăți pentru războiul de țesut, „capete de băț". KEYwORDS: Hurezani, Gorj County, Bronze Age, spindle-whorls, loom-weights, "stick-heads".

\section{Introducere}

Lotul de materiale prezentat provine dintr-o cercetare arheologică preventivă efectuată pentru a elibera terenul de sarcină arheologică în vederea instalării unei conducte de transport gaze naturale în județul Gorj'. Situl arheologic a fost identificat inițial în urma unei evaluări de teren efectuată pentru proiectul BRUA ${ }^{2}$ in comuna Hurezani. Evaluarea de teren a definit situl ca o așezare de epoca bronzului, iar pe baza materialelor arheologice a fost încadrată, inițial, în cultura Verbicioara ${ }^{3}$. Așadar, este vorba de un sit arheologic inedit, care a fost afectat concomitent de două proiecte de investiții diferite. Cercetarea noastră s-a derulat pe o suprafață de aproximativ 4100 din cei $18.000 \mathrm{mp}$ ai sitului, delimitați în urma evaluării. În urma cercetării au fost descoperite și documentate 312 complexe arheologice. Din punct de vedere al încadrării cultural-cronologice cea mai mare parte din complexe aparțin epocii mijlocii a bronzului (cultura Verbicioara) $)^{4}$, dar și grupului Vârtop ${ }^{5}$, din prima epocă a fierului.

Din punct de vedere al contextului de descoperire putem spune că din cele 23 de obiecte prezentate 12 au fost fost

\footnotetext{
1 Mulțumim și pe această cale companiei OMV-Petrom S.A. pentru sprijinul și înțelegerea arătată în cursul cercetărilor arheologice și domnului Gheorghe Calotoiu, responsabilul științific al cercetării, pentru amabilitatea de a ne ceda materialul spre publicare.

2 Colțeanu et al. 2020a, 75-132.

3 Crăciunescu 2004.

4 Verbicioara I - Verbicioara V. Până la clarificarea situației legate de periodizarea culturii Verbicioara, v. Ștefan 2005, 89-100, am folosit periodizarea clasică, v. Berciu 1961, 123-161.

5 Calotoiu, 2012.
} 
descoperite în contexte de locuire, 3 în gropi menajere, iar 7 au fost relevate în urma decopertării mecanizate, deci pot fi considerate passim. Numărul relativ mare al acestor obiecte în contexte arheologice de locuire nu este surprinzător, dacă luăm în considerare faptul că activitățile ce țin de tors și țesut sunt considerate meșteșuguri casnice.

\section{Cadrul natural ${ }^{6}$}

Zona în care s-au desfăşurat cercetările arheologice preventive se află pe malul drept al râului Amaradia Mare, de-a lungul DJ662, DN67B și DN6B, la jumătatea distanței dintre municipiul Târgu Jiu şi municipiul Craiova (55km sud și respectiv nord de acestea), într-o zonă colinară și de trecere spre câmpie. Din punct de vedere administrativ, ne aflăm în sud-estul județului Gorj, în comuna Hurezani, de-a lungul luncii râului Amaradia Mare. Relieful este format din dealuri și văi situate în zona centrală a Piemontului Getic, cu culmi piemontane prelungi, pe direcția monoclinală a stratelor geomorfice, orientate nord-sud, rezultat al mișcărilor neotectonice. Acesta se caracterizează printr-o fragmentare accentuată, datorită văilor scurte și cu pantă mare care s-au format prin eroziune și ca urmare a despăduririlor masive de-a lungul anilor. În evoluția descendentă a suprafeței piemontane din zonă, s-au detaşat trei complexe morfologice: interfluviile, versanţii și văile.

În ceea ce privește suprafața supusă cercetării arheologice preventive, aceasta se situează pe malul drept al râului Amaradia, pe o terasă cu elevația cuprinsă între 150 și 200 m, aceasta având inițial destinația de teren arabil, pășune sau zonă împădurită.

Din punct de vedere geomorfologic, zona este una de afundare, de formație aluvionară. Peisajul natural este compus din dealuri împădurite (cu stejari, frasini, salcâmi, tei etc.) ce delimitează, de o parte și de alta, satele din zona cercetată, dar și zăvoaiele (cu lemn de esență moale - arini, salcie, cătină, plop alb etc.) din albia minoră a Amaradiei. Vegetația aparține zonelor de silvostepă și de dealuri. Fauna zonei se încadrează în biocenoza de climat temperat-continental.

\section{Istoricul cercetărilor}

Până în anul 2018 din aria comunei Hurezani nu se cunoșteau descoperiri arheologice. Ca urmare a unor investiții pentru instalarea unor conducte de transport gaze naturale pe teritoriul comunei au fost identificate mai multe situri arheologice. Este vorba de un sit aflat în apropierea panoului Petrom Hurezani, sit care a fost fost cercetat parțial și cu ocazia construcției stației de comprimare Bibești-Hurezani, pentru proiectul BRUA. În urma cercetărilor s-a putut determina că este vorba de o locuire din cea de a doua epocă a fierului suprapusă de o locuire premodernă. De remarcat însă ca la cercetare au fost identificate şi fragmente ceramice atipice, de epoca bronzului, dar pentru care nu s-a putut face o încadrare culturală mai specifică. Menționăm că această locuire se află la mai puțin de 500 de metri de situl aflat în discuție în acest material. Un alt sit identificat și cercetat aparține secolelor XIV-XV și secolelor XVII-XIX

Tot în anul 2018, în urma unui alt diagnostic arheologic, au fost identificate încă două situri arheologice ${ }^{8}$. Primul dintre ele este o locuire de mici dimensiuni, încadrată cronologic la sfârşitul epocii bronzului și începutul primei epoci a fierului, iar cel de al doilea este reprezentat de situl aflat în discuție în contribuția noastră.

\section{Contextul descoperirilor}

Așa cum am menționat mai sus, lotul de materiale analizate în această contribuție a rezultat în urma cercetării arheologice preventive realizată pe situl numărul 2-39 Hurezani. Din punct de vedere al tipului de așezare vorbim de una deschisă, de mari dimensiuni, așezată pe prima terasă a Amaradiei, mărginită la nord de albia fosilă a râului. În timpul cercetării nu au fost descoperite elemente de fortificaţie. Stratigrafia sitului este reprezentată de patru niveluri culturale clare, cu o grosime a nivelului arheologic cuprinsă între 1,20-1,50 m. Cele patru niveluri de cultură au putut fi delimitate atât de pe adâncimi (stratigrafie verticală) cât și pe baza intersecțiilor de complexe (stratigrafie orizontală). Din punct de vedere al încadrărilor cultural-cronologice generale, cele mai vechi elemente de datare sunt câteva fragmente ceramice Glina III $^{10}$, în afara contextelor arheologice cercetate. Cronologic, urmează contextele Verbicioara I/Verbicioara II reprezentate prin două locuințe și mai multe gropi menajere. Acest nivel este acoperit de un strat de pământ galben, probabil o prăbuşire a coastei terasei a doua, cu o grosime medie de $20 \mathrm{~cm}$, nivel perforat de complexele nivelului Verbicioara IV. De pe acest nivel $(-0,50-1,00 \mathrm{~m})$ se conturează

\footnotetext{
Colțeanu et al. 2020b, 133-162.

Colțeanu et al. 2020a, 75-132.

8 Colțeanu et al. 2020a, 140-144.

9 Sit 2/ 2018 Petrom Totea - Sit 32018 BRUA, Cod RAN 80515.04.

10 Schuster 1997; Băjenaru 2014.
} 


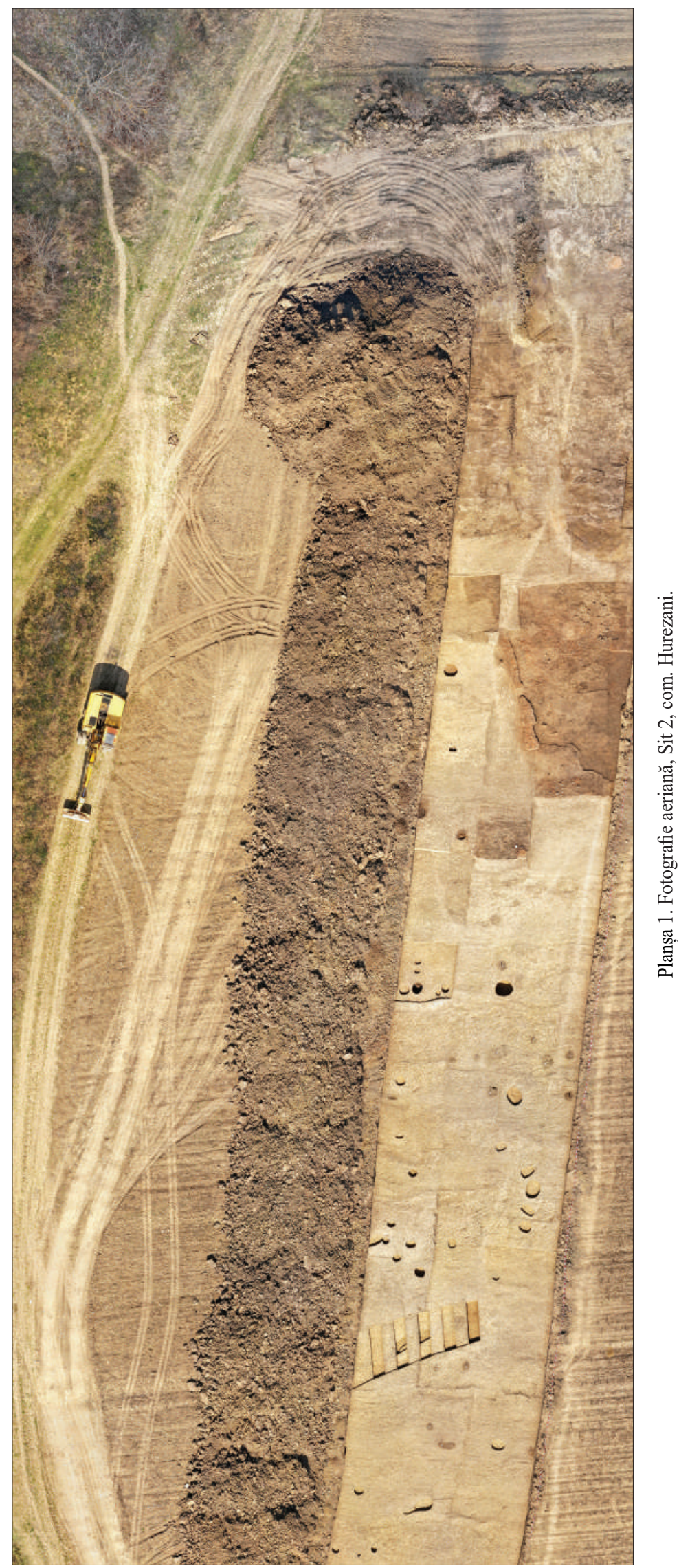




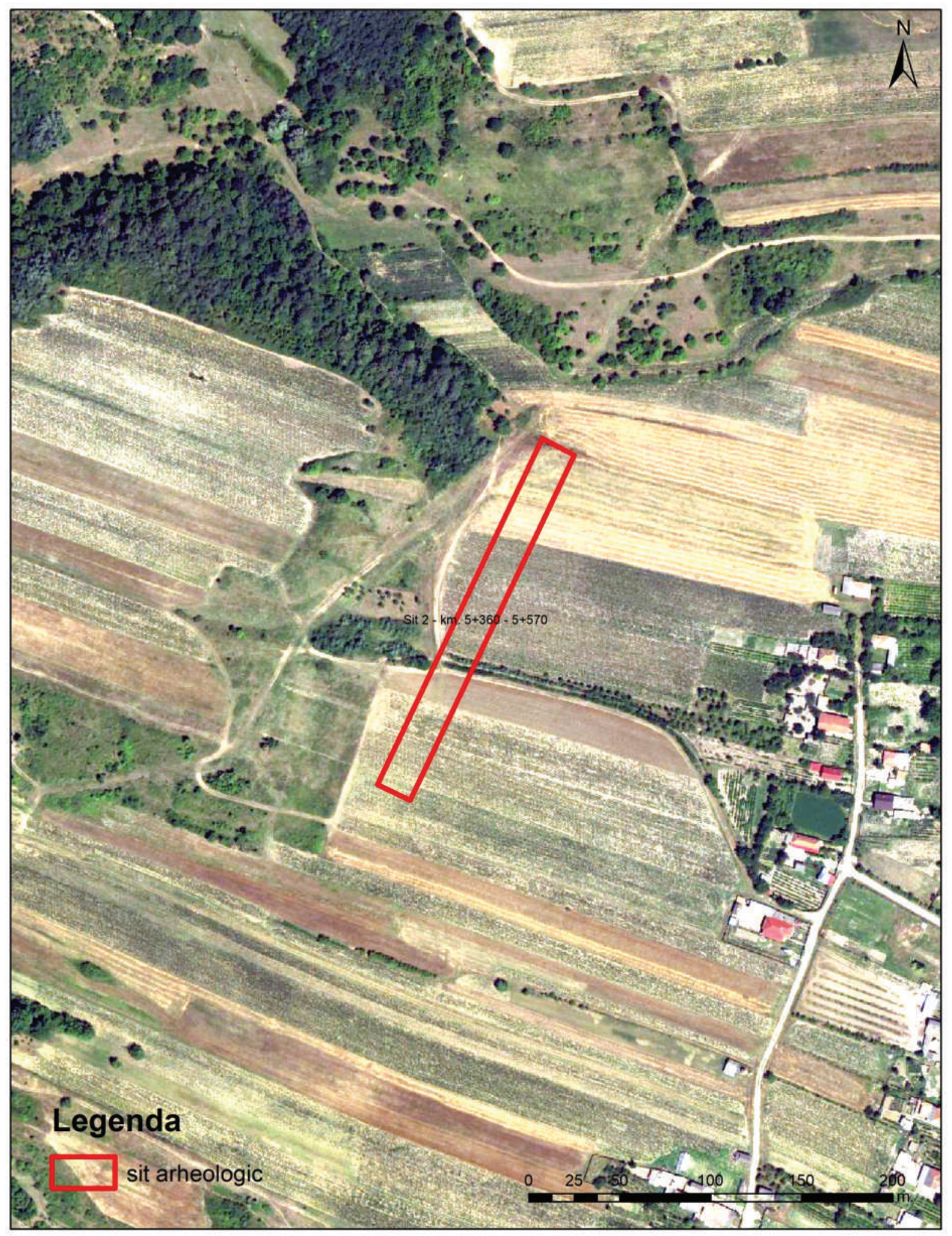

Planșa 2. Ortofotoplanul Sitului 2, com. Hurezani. 


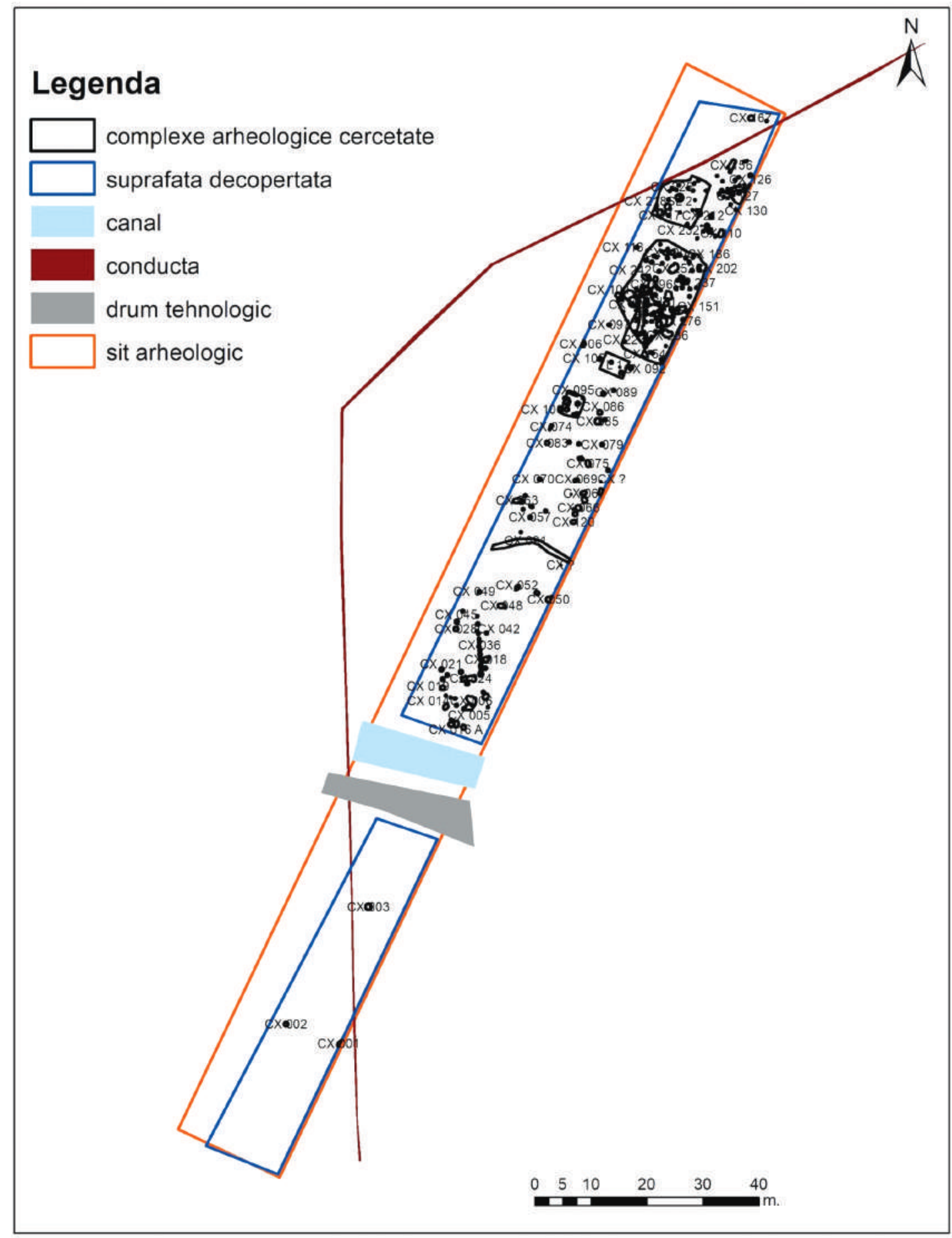

Planșa 3. Plan general de săpătură, Sit 2, com. Hurezani. 
stratul de cultură Verbicioara IV, cel mai consistent de altfel (la acest nivel al prelucrării datelor vorbim de peste 150 de contexte arheologice care pot fi puse în legătură cu acesta). Nivelul Verbicioara IV este suprapus de un nivel de cultură Verbicioara V și de unul aparținând grupului Vîrtop, în mare parte distruse de lucrările agricole, dar din care au putut totuşi să fie cercetate mai multe complexe care aparțin epocii târzii a bronzului și primei epoci a fierului din Oltenia.

În cadrul acestei lucrări, vom aduce în discuție date tehnice despre fusaiolele, greutățile pentru războiul de țesut vertical, dar şi despre o categorie de artefacte intrate în istoriografie cu denumirea de capete de băț ${ }^{11}$.

\section{Metodologia de cercetare}

Din punct de vedere metodologic, vom utiliza modelul propus de CTR ${ }^{12}$ și preluat, la nivel național, de cercetători precum Paula Mazăre ${ }^{13}$ și Dănuț Prisecaru ${ }^{14}$. Astfel, pentru lotul de materiale reprezentat de fusaiole vom ține cont de categoria morfo-funcțională (vom înregistra materia primă din care au fost confecționate artefactele, atât pentru fusaiole și greutăți, cât și pentru „,capetele de băț”), clasa de mărime $e^{15}$, tipul perforației (orificii cilindrice, conice și bitronconice), grupa tipologică ${ }^{16}$ și tipul morfologic (fusaiole cilindrice, sferice/discoidale, semisferice, biconvexe, tronconice, și bitronconice) $)^{17}$.

În ceea ce privește analiza macroscopică utilizată în cazul greutăților folosite la războiul de țesut vertical, vom ține cont de categoria morfo-funcțională (va fi folosit același model ca în cazul fusaiolelor), de forma artefactelor, de dimensiunile (inclusiv diametrul maxim al perforației, deoarece este foarte important, și, precum masa artefactului, ne poate sugera, cu aproximație, câte fire au fost tensionate) şi masa acestora.

Pentru repertorierea artefactelor, specifice torsului și țesutului în perioada de timp menționată, am avut în vedere următoarele criterii: contextul arheologic, dimensiunile $\left(\mathrm{D}_{\max .}=\right.$ diametrul maxim, $\mathrm{D}_{\text {min. }}=$ diametrul minim, $\mathrm{h}=$ înălțimea, $\mathrm{D}_{\text {perf. }}=$ diametrul perforației, toate dimensiunile fiind trecute în centrimetri; $\mathrm{G}=$ masa artefactului, trecută în grame) și forma pieselor, materia primă din care au fost confecţionate, starea de conservare, încadrarea cronologică şi/sau culturală, bibliografie și/sau analogii și, nu în ultimul rând, observaţii suplimentare (acolo unde este cazul) privind aspectul piesei, calitatea producerii, decor, semne sau particularități etc.

\footnotetext{
11 Marc 2012, 92.

12 (http://ctr.hum.ku.dk/) vizualizat pe data 28.02.2020.

13 Mazăre 2012, 110-118.

14 Prisecaru 2014, 40-43.

15 Mazăre 2012, 115-116.

16 Mazăre 2012, Tabel 4.

17 Prisecaru 2014, Fig. 15.
} 


\section{Catalog}

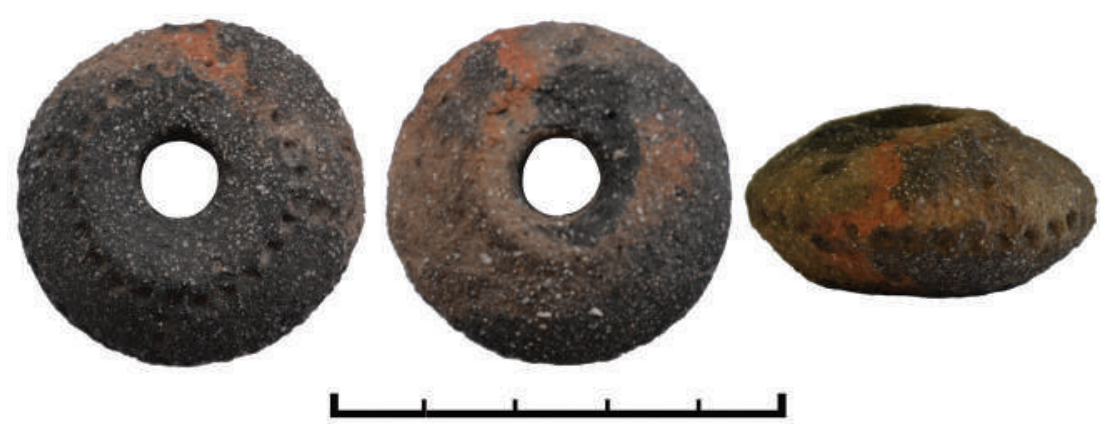

Figura 1. Fusaiolă bitronconică

1.

a) Decapare/ Passim

b) Dmax. $=3,7 \mathrm{~cm}, \mathrm{~h}=1,7 \mathrm{~cm}, \mathrm{G}=22,94 \mathrm{~g}$, Dperf. $=0,8 \mathrm{~cm}$, fusaiolă bitronconică $(6 \mathrm{~B})$, perforație cilindrică.

c) Confecționată din lut ars.

d) Stare bună de conservare.

e) Epoca bronzului.

f) Inedit; Analogii: Berciu, Comșa, Popescu-Ialomița 1951, Fig. 12.

g) Figura 1. Artefactul prezintă un model format din împunsături, plasat în jurul diametrului maxim și pe una dintre fețele fusaiolei, în jurul perforației.

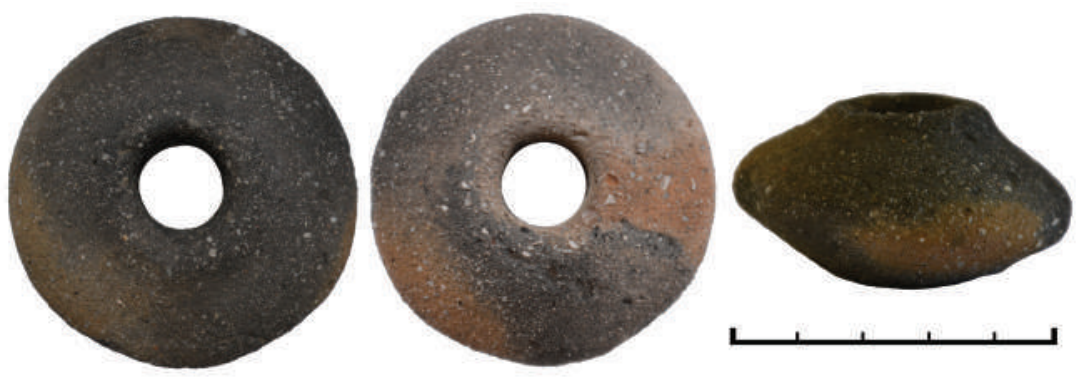

Figura 2. Fusaiolă bitronconică

2.

a) Decapare/ Passim.

b) Dmax. $=5,2 \mathrm{~cm}$, Dmin. $=2,6 \mathrm{~cm}, \mathrm{~h}=2,6 \mathrm{~cm}, \mathrm{G}=59 \mathrm{~g}$, Dperf. $=1,4 \mathrm{~cm}$, fusaiolă bintronconică $(6 \mathrm{~B})$, perforație cilindrică.

c) Confecționată din lut ars.

d) Stare bună de conservare.

e) Epoca bronzului.

f) Inedit; Analogii: Crăciunescu 2004, Planșa XXXVII/ 6.

g) Figura 2 . 


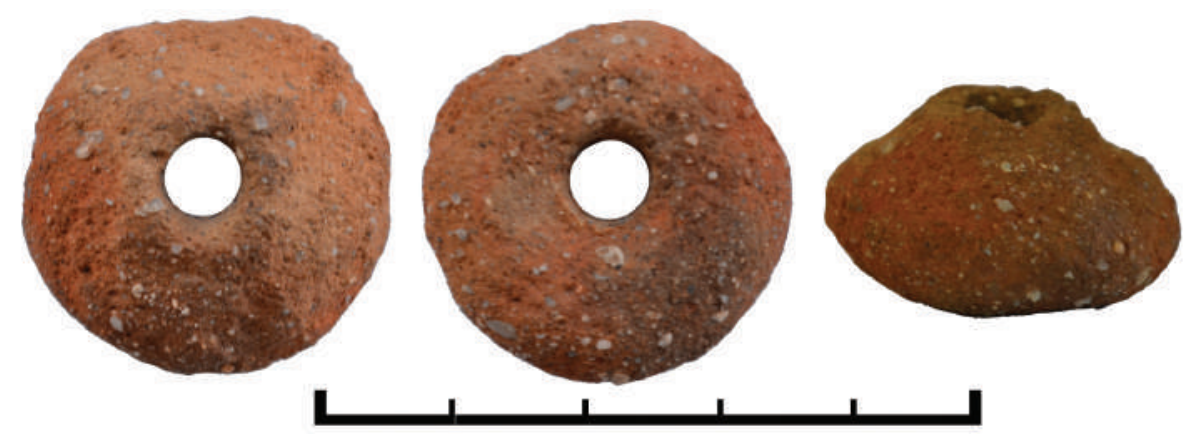

Figura 3. Fusaiolă bitronconică.

3.

a) $\quad$ Cx 14. Groapă de resturi menajere.

b) Dmax. $=2,7 \mathrm{~cm}, \mathrm{~h}=1,4 \mathrm{~cm}, \mathrm{G}=9,40 \mathrm{~g}$

c) Confecționată din lut ars.

d) Stare bună de conservare.

e) Epoca bronzului. Cultura Verbicioara, faza IV (după Berciu).

f) Inedit. Analogii: Crăciunescu 2004, Planșa LXXXIX/ 1.

g) Figura 3.

4.

a) Decapare/Passim.

b) Dmax. $=3,2 \mathrm{~cm}, \mathrm{~h}=2,4 \mathrm{~cm}, \mathrm{G}=20 \mathrm{~g}$, Dperf. $=1 \mathrm{~cm}$, ,capăt de băț” tip IVa, perforație cilindrică.

c) Confectionat din lut ars.

d) Stare bună de conservare.

e) Epoca bronzului.

f) Inedit; Analogii: Rustoiu 1995, Planșa1; Schuster, Tuțulescu, Negru, 2014, Pl.1/1.

g) Figura 4.
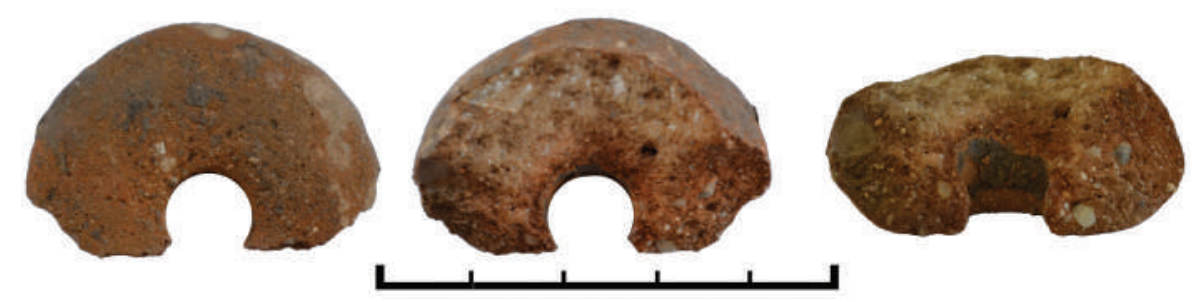

Figura 5. Fusaiolă discoidală.

5.

a) Cx 127. Bordei 1 .

b) Dmax. $=3,7 \mathrm{~cm}$, Dmin. $=2,4 \mathrm{~cm}, \mathrm{~h}=1,5 \mathrm{~cm}, \mathrm{G}=11,90 \mathrm{~g}$, Dperf. $=0,8 \mathrm{~cm}$, fusaiolă discoidală $(2 \mathrm{~B})$, perforație cilindrică.

c) Confecționată din lut ars.

d) Stare medie de conservare, fusaiolă fragmentară.

e) Epoca bronzului. Cultura Verbicioara, faza IV (după Berciu).

f) Inedit.

g) Figura 5. 


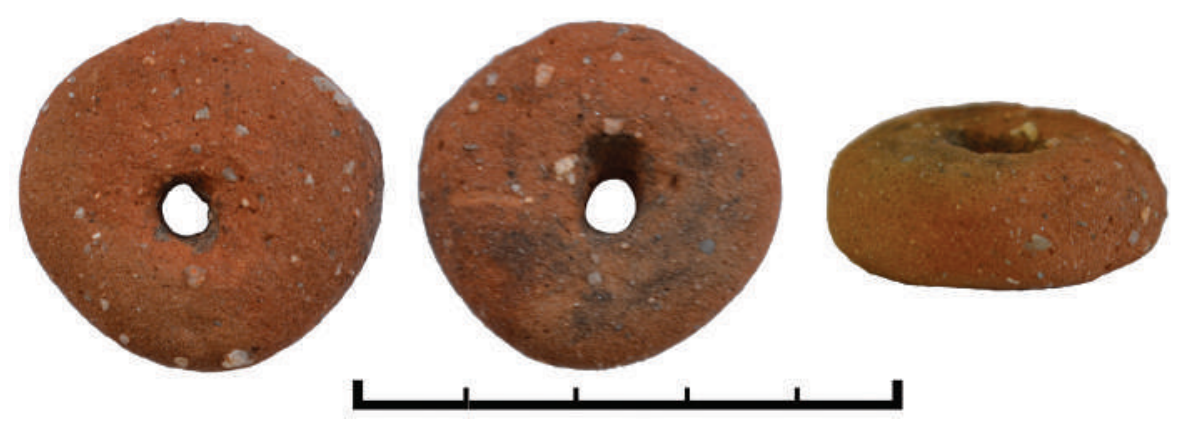

Figura 6. Fusaiolă discoidală.

6.
a) SL. 1. 9 .

b) Dmax. $=3,2 \mathrm{~cm}, \mathrm{~h}=1,2 \mathrm{~cm}, \mathrm{G}=14 \mathrm{~g}$, Dperf. $=0,7 \mathrm{~cm}$, fusaiolă discoidală $(2 \mathrm{~B})$, perforație cilindrică.

c) Confecționată din lut ars.

d) Stare bună de conservare.

e) Epoca bronzului. Cultura Verbicioara, faza IV (după Berciu).

f) Inedit; Analogii: Calotoiu, Hortopan, 2008, Planșa XVIII.

g) Figura 6 .

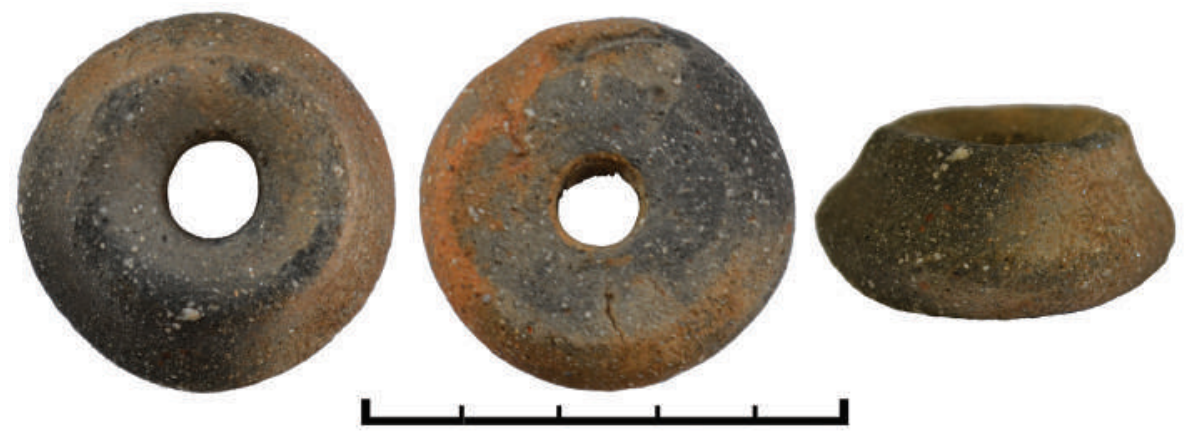

Figura 7. Fusaiolă bitronconică.

7.

a) SL 1. 18 .

b) Dmax. $=3,7 \mathrm{~cm}$, Dmin. $=2,8 \mathrm{~cm}, \mathrm{~h}=1,8 \mathrm{~cm}, \mathrm{G}=25,37 \mathrm{~g}$, Dperf. $=0,9 \mathrm{~cm}$, fusaiolă bitronconică $(6 \mathrm{~A})$, perforație cilindrică.

c) Confecționată din lut ars.

d) Stare bună de conservare.

e) Epoca bronzului. Cultura Verbicioara, faza IV (după Berciu).

f) Inedit.

g) $\quad$ Figura 7. Prezintă urme de ardere secundară.
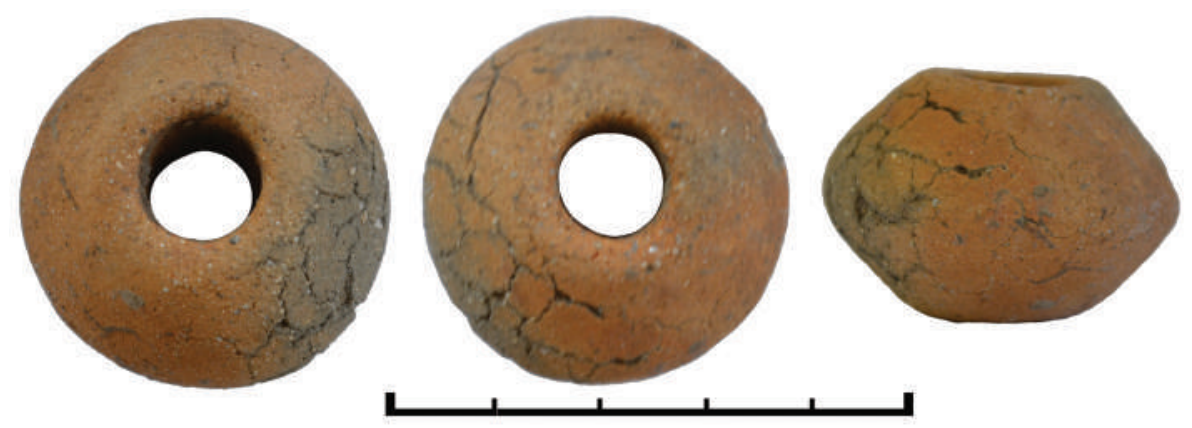

Figura 8. Fusaiolă bitronconică.

8.

a) $\quad$ Cx 127. Bordei 1 .

b) Dmax. $=3,4 \mathrm{~cm}, \mathrm{~h}=2,3 \mathrm{~cm}, \mathrm{G}=22 \mathrm{~g}$, Dperf. $=1 \mathrm{~cm}$, fusaiolă bitronconică $(6 \mathrm{C})$, perforație cilindrică.

c) Confecționată din lut ars.

d) Stare bună de conservare.

e) Epoca bronzului. Cultura Verbicioara, faza IV (după Berciu).

f) Inedit; Analogii: Crăciunescu, 2004, Planșa XXXVII/6; Planșa XXXVIII/1; XCII/1.

g) Figura 8 . 

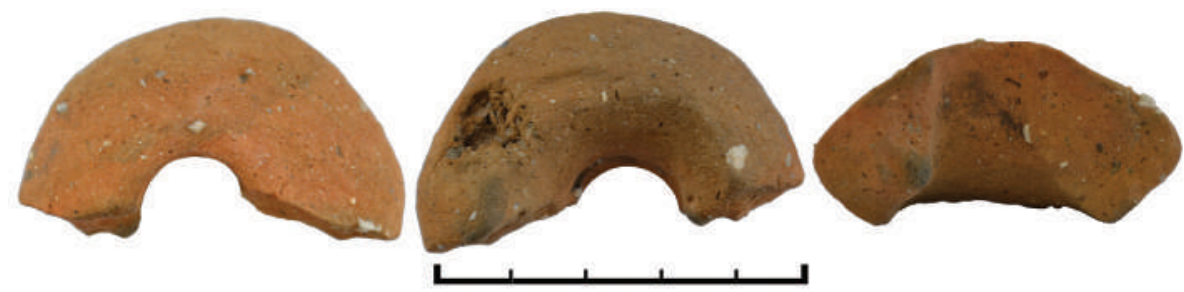

Figura 9. Fusaiolă bitronconică.

9.

a) Decapare/ Passim.

b) Dmax. $=5 \mathrm{~cm}$, Dmin. $=2,4 \mathrm{~cm}, \mathrm{~h}=2,5 \mathrm{~cm}, \mathrm{G}=27 \mathrm{~g}$, Dperf. $=1,3 \mathrm{~cm}$, fusaiolă bitronconică $(6 \mathrm{~B})$, perforație cilindrică.

c) Confecționată din lut ars.

d) Stare bună de conservare.

e) Epoca bronzului.

f) Inedit.

g) Figura 9.
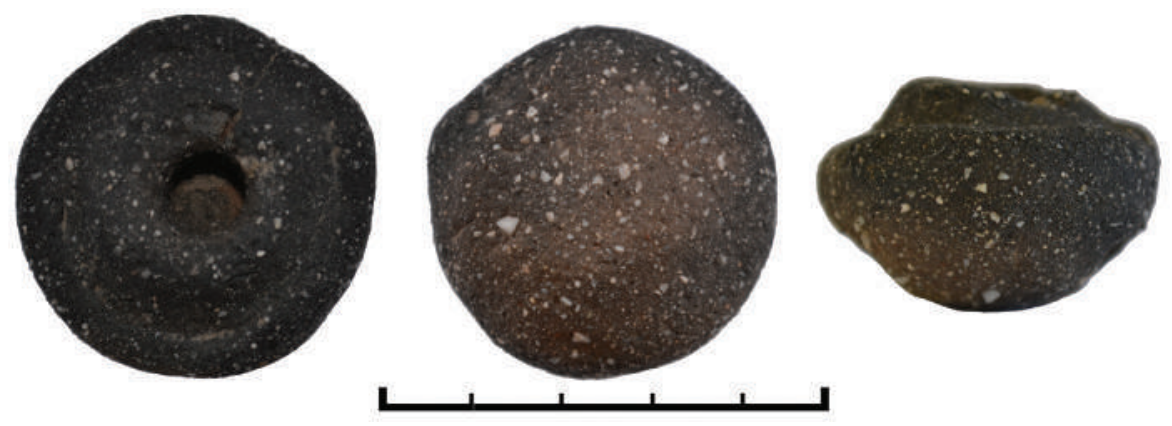

Figura 10. „Capăt de băț”, tip IId

10.

a) L. 1. Locuință de Suprafață

b) Dmax. $=3,8 \mathrm{~cm}$, Dmin. $=2,1 \mathrm{~cm}, \mathrm{~h}=2,3 \mathrm{~cm}, \mathrm{G}=34,80 \mathrm{~g}$, Dperf. $=0,8 \mathrm{~cm}$, „capăt de băț” tip IId, perforație cilindrică.

c) Confecționat din lut ars.

d) Stare bună de conservare.

e) Epoca bronzului. Cultura Verbicioara, faza IV (după Berciu).

f) Inedit; Analogii: Marc 2012, Pl. III; Rustoiu 1995, Planșa 1.

g) Figura 10.
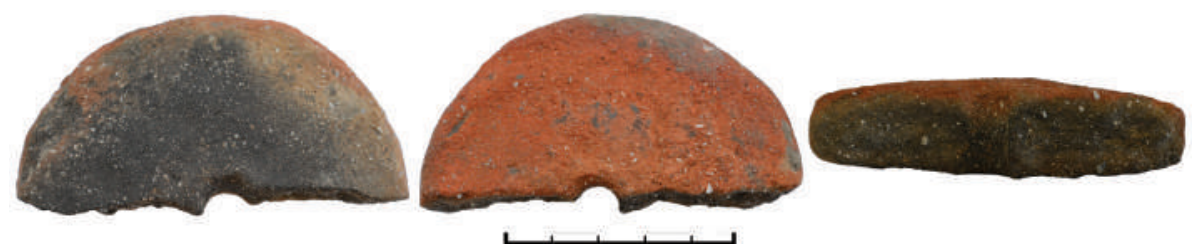

Figura 11. Greutate pentru războiul de țesut, discoidală.

11.

a) Decapare/ Passim.

b) Dmax. $=8,1 \mathrm{~cm}$, Dmin. $=3,9 \mathrm{~cm}, \mathrm{~h}=1,7 \mathrm{~cm}, \mathrm{G}=77,53 \mathrm{~g}$, Dperf. $=0,9 \mathrm{~cm}$, greutate pentru războiul de țesut vertical, formă discoidală, perforație cilindrică.

c) Confecționată din lut ars.

d) Stare medie de conservare, fusaiolă fragmentară.

e) Epoca bronzului.

f) Inedit; Analogii: Crăciunescu, 2004, Planșa XXXVII/7; Calotoiu, Hortopan, 2008, Planșa XVIII.

g) Figura 11. 


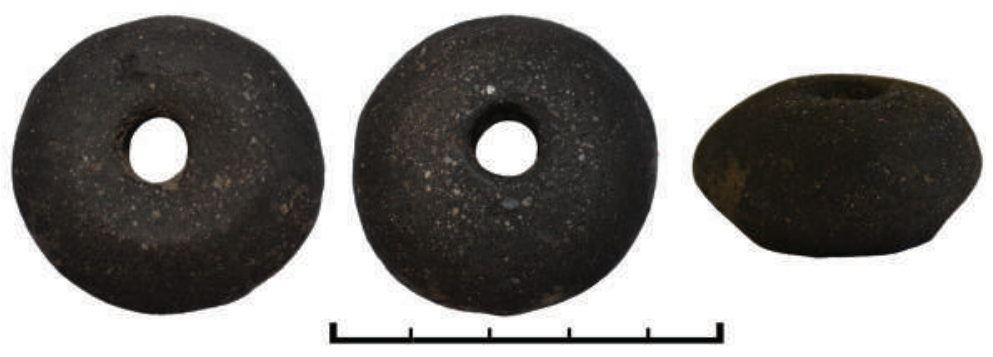

Figura 12. Fusaiolă bitronconică

12.

a) SL. 2. 1 .

b) Dmax. $=3,8 \mathrm{~cm}$, Dmin. $=2,5 \mathrm{~cm}, \mathrm{~h}=2,1 \mathrm{~cm}, \mathrm{G}=30,62 \mathrm{~g}$, Dperf. $=0,8 \mathrm{~cm}$, fusaiolă bitronconică $(6 \mathrm{C})$, perforație cilindrică.

c) Confecționată din lut ars.

d) Stare bună de conservare.

e) Epoca bronzului. Cultura Verbicioara, faza V (după Berciu).

f) Inedit. Analogii: Crăciunescu, 2004, Planșa XXXVII/6.

g) Figura 12.

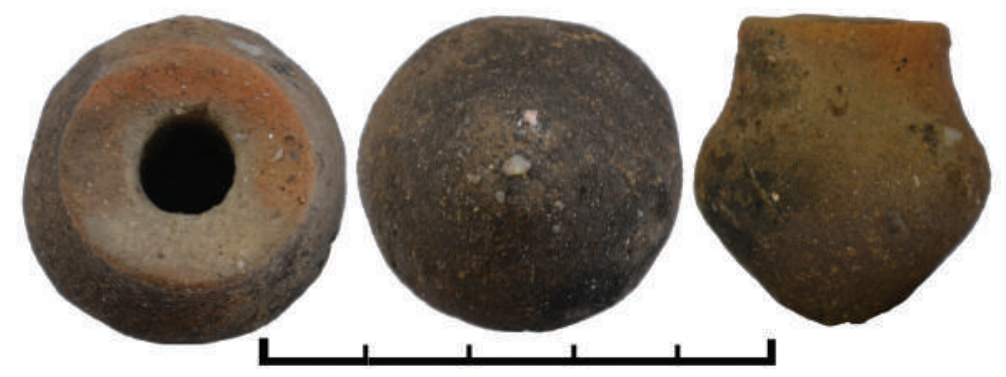

Figura 13. „Capăt de băţ”, tip IId (formă vas).

13.

a) S.L 2.ם1.

b) Dmax. $=3 \mathrm{~cm}$, Dmin. $=2,1 \mathrm{~cm}, \mathrm{~h}=3,1 \mathrm{~cm}, \mathrm{G}=24,15 \mathrm{~g}$, Dperf. $=0,8 \mathrm{~cm}$, „capăt de băț” tip IId (formă de vas), perforație cilindrică.

c) Confecționat din lut ars.

d) Stare bună de conservare.

e) Epoca bronzului. Cultura Verbicioara, faza V (după Berciu).

f) Inedit; Analogii: Berciu, Comşa, Popescu-Ialomița 1951: Fig. 12; Rustoiu 1995, Planșa 1;

g) Figura 13.

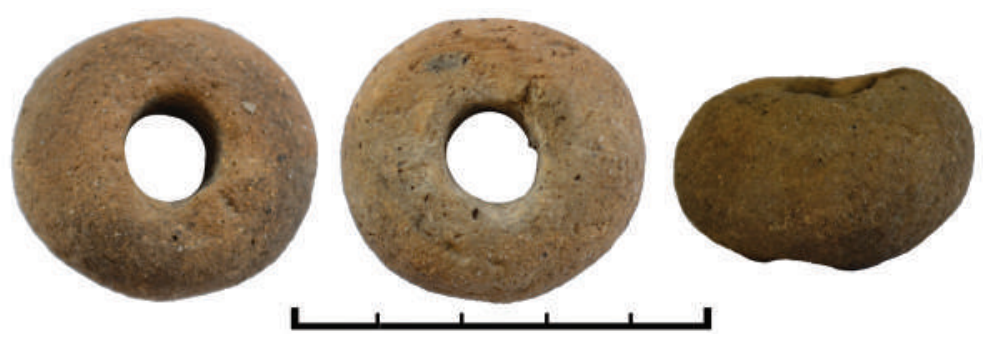

Figura 14. Fusaiolă discoidală.

14.

a) Cx.127. Bordei 1 .

b) Dmax. $=3,5 \mathrm{~cm}, \mathrm{~h}=2,1 \mathrm{~cm}, \mathrm{G}=20 \mathrm{~g}$, Dperf. $=1,1 \mathrm{~cm}$, fusaiolă discoidală (2B), perforație cilindrică.

c) Confecționată din lut ars.

d) Stare bună de conservare.

e) Epoca bronzului.

f) Inedit. Analogii: Crăciunescu, 2004, Planșa LXXXIX/4.

g) Figura 14. 


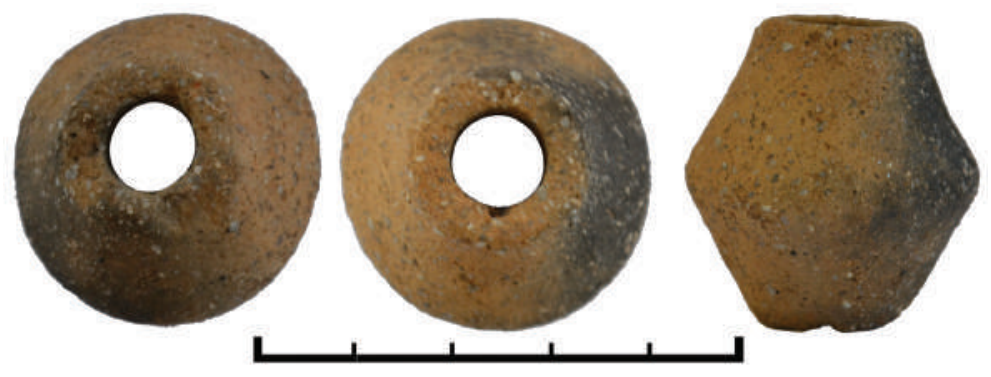

Figura 15. Fusaiolă bitronconică

15.

a) Decapare/Passim

b) Dmax. $=3 \mathrm{~cm}$, Dmin. $=1,8 \mathrm{~cm}, \mathrm{~h}=3,1 \mathrm{~cm}, \mathrm{G}=24,25 \mathrm{~g}$, Dperf. $=0,9 \mathrm{~cm}$, fusaiolă bitronconică $(6 \mathrm{D})$, perforație cilindrică.

c) Confecționată din lut ars.

d) Stare bună de conservare.

e) Epoca bronzului.

f) Inedit. Analogii: Crăciunescu, 2004, Planșa LXXXIX/3.

g) Figura 15.

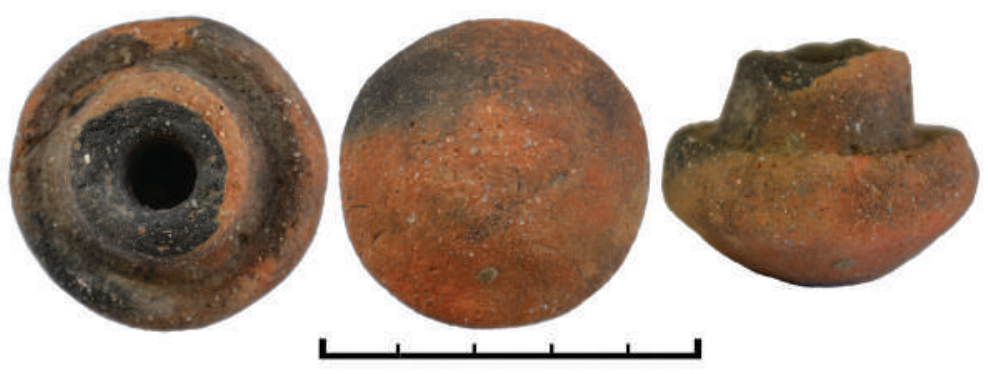

Figura 16. „Capăt de băț”, tip IIc.

16.

a) Decapare/ Passim.

b) Dmax. $=4 \mathrm{~cm}$, Dmin. $=2,2 \mathrm{~cm}, \mathrm{~h}=2,9 \mathrm{~cm}, \mathrm{G}=37,64 \mathrm{~g}$, Dperf. $=0,8 \mathrm{~cm}$, ,capăt de băț” tip IIc, perforație cilindrică.

c) Confecționat din lut ars.

d) Stare bună de conservare.

e) Epoca bronzului.

f) Inedit; Analogii: Berciu, Comşa, Popescu-Ialomița 1952: Fig. 13; Marc 2012, Pl. II; Rustoiu 1995, Planşa 1; Calotoiu, 2002, Planșa 2.

g) $\quad$ Figura 16. Prezintă urme de ardere secundară.

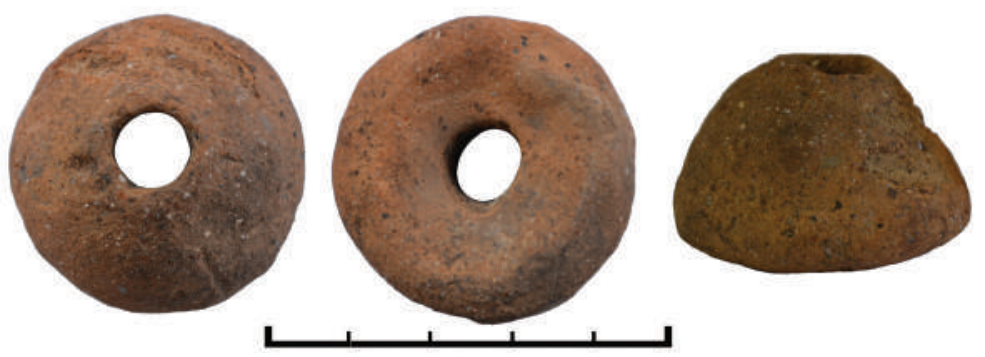

17.

Figura 17. Fusaiolă tronconică

a) Cx.67. Groapă de resturi menajare.

b) Dmax. $=3,5 \mathrm{~cm}$, Dmin. $=1,6 \mathrm{~cm}, \mathrm{~h}=2,2 \mathrm{~cm}, \mathrm{G}=24,18 \mathrm{~g}$, Dperf. $=0,9 \mathrm{~cm}$, fusaiolă tronconică $(5 \mathrm{C})$, perforație cilindrică.

c) Confecționată din lut ars.

d) Stare bună de conservare.

e) Prima epocă a Fierului. Grupul Vârtop.

f) Inedit.

g) Figura 17. 


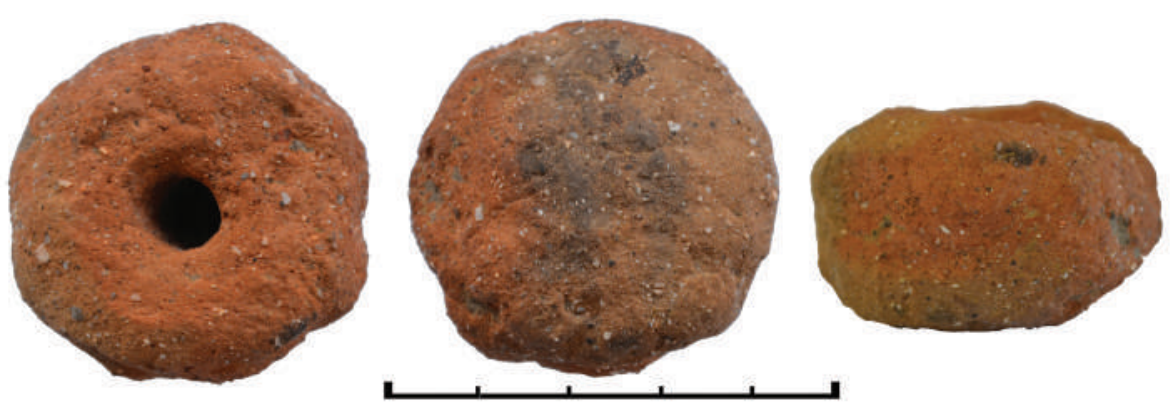

Figura 18. „Capăt de băț”, tip I.

18.
a) SL. 1. 9 .

b) Dmax. $=3,9 \mathrm{~cm}, \mathrm{~h}=2,4 \mathrm{~cm}, \mathrm{G}=38,61 \mathrm{~g}$, Dperf. $=0,8 \mathrm{~cm}$, , ,capăt de băț’ tip I, perforație cilindrică.

c) Confecționat din lut ars.

d) Stare bună de conservare.

e) Epoca bronzului. Cultura Verbicioara, faza IV (după Berciu).

f) Inedit; Analogii: Berciu 1961, Abb. 12, 4.

g) Figura 18.
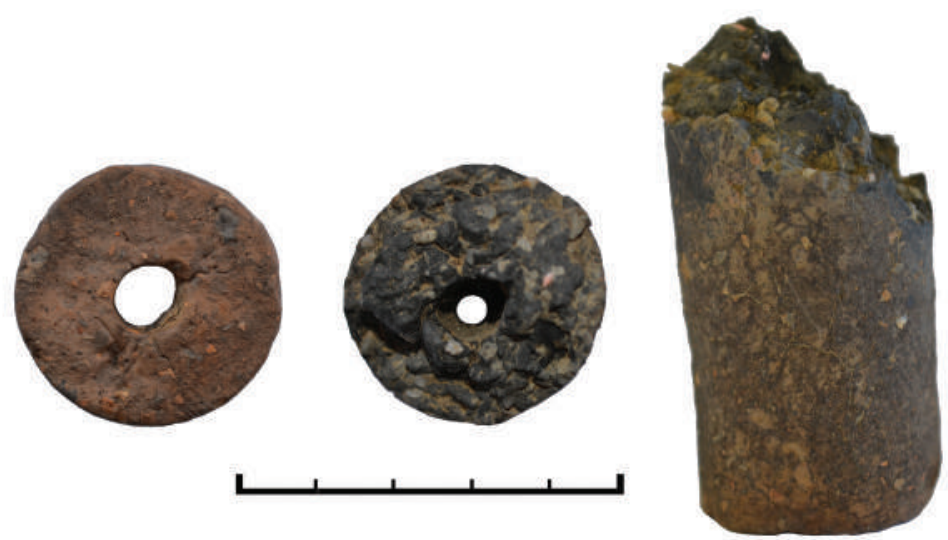

Figura 19. Fusaiolă cilindrică

19.
a) SL. 1. $\square 9$.

b) Dmax. $=3,2 \mathrm{~cm}, \mathrm{~h}=6,2 \mathrm{~cm}, \mathrm{G}=69,37 \mathrm{~g}$, Dperf. $=0,9 \mathrm{~cm}$, fusaiolă cilindrică (1D), perforație cilindrică.

c) Confecționată din lut ars.

d) Stare bună de conservare.

e) Epoca bronzului. Cultura Verbicioara, faza IV (după Berciu).

f) Inedit. Analogii: Crăciunescu, 2004, Planşa LXXXVII/3.

g) Figura 19.
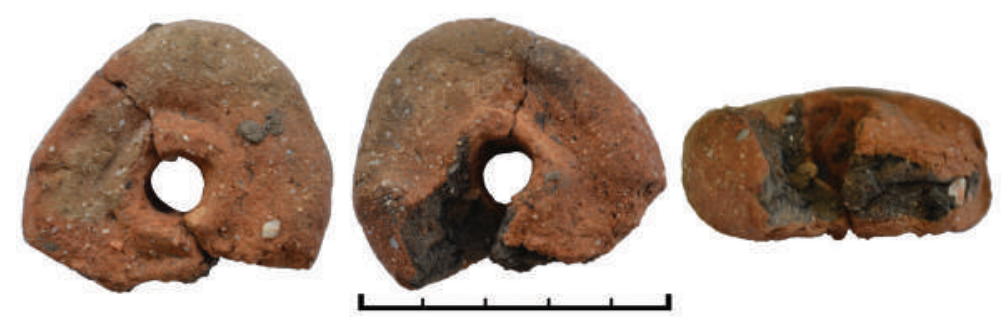

Figura 20. Fusaiolă cilindrică

20.

a) L.1. Locuință de Suprafață

b) Dmax. $=4,8 \mathrm{~cm}, \mathrm{~h}=1,9 \mathrm{~cm}, \mathrm{G}=37,93 \mathrm{~g}$, Dperf. $=0,9 \mathrm{~cm}$, fusaiolă cilindrică (1B), perforație cilindrică.

c) Confecționată din lut ars.

d) Stare bună de conservare, fusaiolă fragmentară.

e) Epoca bronzului, cultura Verbicioara.

f) Inedit.

g) Figura 20. 


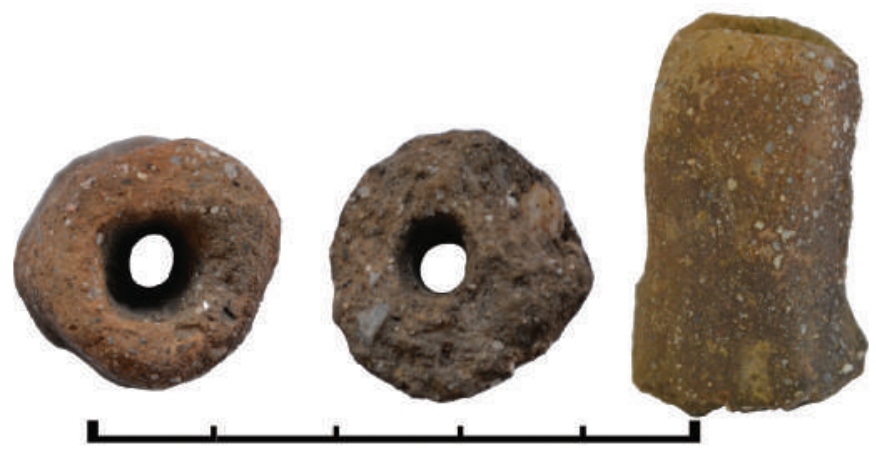

Figura 21. Fusaiolă cilindrică.

21.

a) $\quad \mathrm{Cx} 127$. Bordei 1 .

b) Dmax. $=1,8 \mathrm{~cm}, \mathrm{~h}=3,1 \mathrm{~cm}, \mathrm{G}=13,28 \mathrm{~g}$, Dperf. $=0,7 \mathrm{~cm}$, fusaiolă cilindrică (1D), perforație cilindrică.

c) Confecționată din lut ars.

d) Stare bună de conservare.

e) Epoca bronzului. Cultura Verbicioara, faza IV (după Berciu)

f) Inedit. Analogii: Crăciunescu, 2004, Planșa LXXXVII/3.

g) Figura 21.

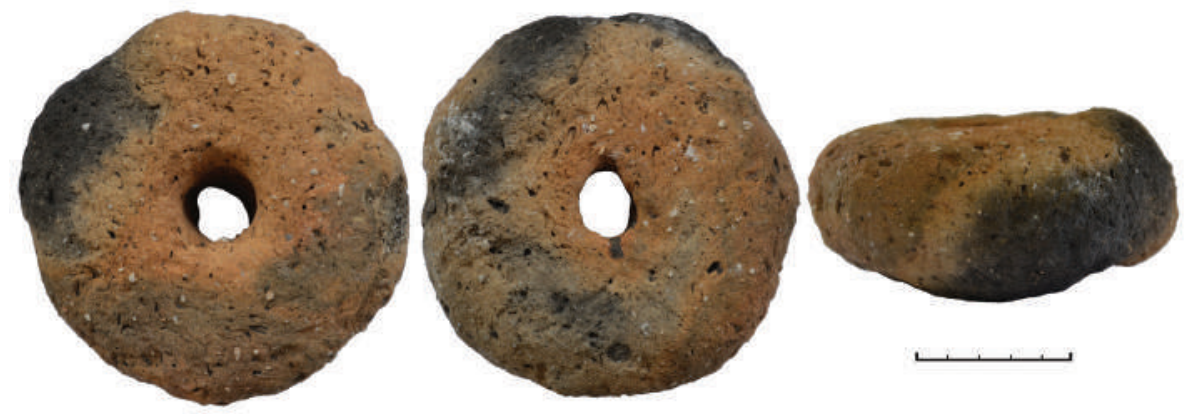

Figura 22. Greutate pentru războiul de țesut, discoidală.

22.

a) Cx. 230A. Groapă de resturi menajere.

b) Dmax. $=11,53 \mathrm{~cm}, \mathrm{~h}=4,8 \mathrm{~cm}, \mathrm{G}=538 \mathrm{~g}$, Dperf. $=2 \mathrm{~cm}$, greutate pentru războiul de țesut vertical, formă discoidală, perforație cilindrică.

c) Confecționată din lut ars.

d) Stare bună de conservare.

e) Epoca bronzului. Cultura Verbicioara, faza IV (după Berciu).

f) Inedit.

g) $\quad$ Figura 22. Prezintă urme de ardere secundară.

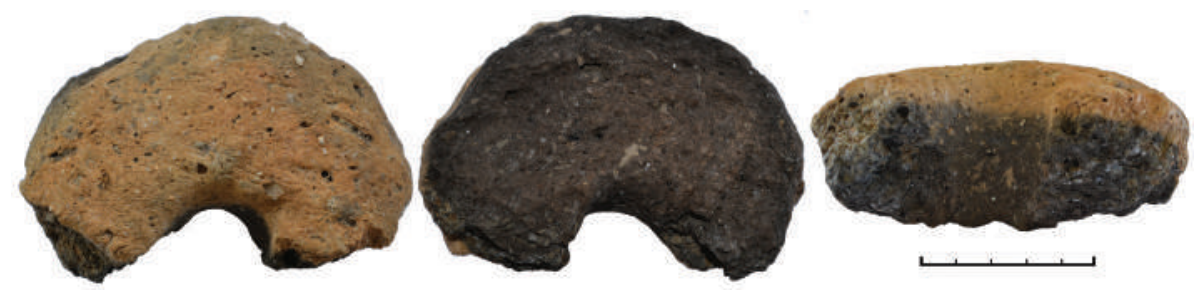

Figura 23. Greutate pentru războiul de țesut, discoidală.

23.

a) Cx. 230 A. Groapă de resturi menajere.

b) Dmax. $=10,16 \mathrm{~cm}$, Dmin. $=6,97 \mathrm{~cm}, \mathrm{~h}=4 \mathrm{~cm}, \mathrm{G}=235,23 \mathrm{~g}$, Dmax.perf. $=3,2 \mathrm{~cm}$, Dmin.perf. $=1,7$ $\mathrm{cm}$, greutate pentru războiul de țesut vertical, formă discoidală, perforație tronconică.

c) Confecționată din lut ars.

d) Stare bună de conservare, greutate fragmentară.

e) Epoca bronzului. Cultura Verbicioara, faza IV (după Berciu)

f) Inedit.

g) Figura 23. 


\section{Analiza materialelor}

În primul rând toate obiectele analizate sunt din lut, pasta este de cele mai multe ori semifină, cu pietricele. Decorul este prezent doar pe două fusaiole bitronconice din lot, la una pe zona mediană, iar la cealaltă pe unul din capete, în zona perforației, și este reprezentat prin împunsături succesive.

Pentru clasa de mărime a fusaiolelor și a „,capetelor de băț” am constatat următoarele valori:

- $\quad$ Foarte mici: una;

- Mici: opt;

- Medii: trei;

- Mari: trei;

„Capetele de băț” le-am considerat ca aparținând categoriei obiectelor legate de tors ${ }^{18}$ și le-am tratat tinând cont de greutate, înălțime și diamentru, adică posibilele atribute funcționale ale acestora ${ }^{19}$. Conform acestor considerente am constatat următoarele valori:

- Mici: două;

- Mediu: unul;

- Mari: două;

În privinţa tipului morfologic al artefactelor din categoria fusaiole și capete de băț se disting următoarele forme:

- $\quad$ Cilindrice: trei fusaiole (1B - una; 1D - două);

- Discoidale: trei (2B);

- Tronconice: o fusaiolă $(5 \mathrm{C})$;

- $\quad$ Bitronconice: 8 ( 6A - una; 6B - patru; 6C - două și 6D - una).

Situaţia din punct de vedere al tipului morfologic al „,capetelor de băț” se prezintă în felul următor:

- Discoidal: unul (I)

- $\quad$ Bitronconice: trei ( IVA - două; IID - unul).

În ceea ce privește forma greutăților pentru războiul de țesut vertical avem trei discoidale cu perforație mediană. Toate categoriile de artefacte au perforație cilindrică.

Forma și greutatea fusaiolelor sunt direct proporționale cu tipul și grosimea firului rezultat în urma toarcerii. Astfel, pentru prelucrarea unor fibre ușoare, precum și pentru obținerea unui fir mai fin (utilizat în producerea unei țesături mai fine, de bună calitate) este necesară folosirea unei fusaiole mai ușoare (până în $35 \mathrm{~g}$ ). Fusaiolele medii (de 40-50 g) sunt folosite pentru obținerea unor fire mai groase sau mai lungi (similare celor utilizate la țeserea unor pături sau a unor piese vestimentare mai groase), pe când fusaiolele mari și foarte mari sunt folosite în prelucrarea unor fibre dure, mai lungi și mult mai groase, precum cele din in, cânepă sau urzică. De exemplu, dacă se utilizează o fusaiolă uşoară cu diamentrul mic (forme rotunjite), se vor obține fire mai scurte, în schimb, dacă se toarce cu ajutorul unei fusaiole ușoare, dar cu diametru mare (forme aplatizate) se vor obține fire mai lungi ${ }^{20}$. Utilizând datele unui experiment arheologic realizat de către CTR, în care autorii au propus un model de calcul al producerii unui metru pătrat de țesătură pe baza masei și înălțimii unei greutăți pentru războiul de țesut vertical, am analizat singura greutate întreagă (nr. 22 din catalog) înregistrată în repertoriul nostru. Calculele făcute pentru această greutate au arătat că țesătura rezultată ar fi avut între 5 și 10-11 fire/centimetru şi, aproximativ, între 10 și 30 de fire tensionate per greutate.

Asocierea descoperirilor în contextele arheologice cercetate oferă o serie de date, considerăm noi interesante. Astfel, din cele 23 de piese prezentate 16 provin din contexte care au putut fi definite (locuințe sau gropi menajere). Complexele 14 și 67 sunt gropi menajere. Din complexul 14 a fost recuperată o fusaiolă de tip 6B (Nr. cat. 3/Pl.3), iar din Complexul 67 o fusaiolă de tip 5C (Nr. cat. 17/P1.17). Din complexul 127/Bordei 1 au fost recuperate patru fusaiole. Ele sunt una de tipul 1D (Nr. cat. 21/P1.21), una de tipul 6C (Nr. cat. 8/P1.8) și două de tipul 2B (Nr. cat. 5 și 14/Pl.5; Pl. 14). În locuința 1 (L1) au fost descoperite o fusaiolă de tip 1D (Nr. cat. 20/P1 20) și un ,,capăt de băț” de tip IID (Nr. cat. 10/P1. 10). Din suprafața locuită SL1 (locuință incendiată de mari dimensiuni) provin trei fusaiole şi un „capăt de băț”. Din caroul 8 o fusaiolă de tip 6A (Nr. cat. 7/P1. 7). Din caroul 9 provin o fusaiolă de tip 2B (Nr. cat. 6/Pl. 6), o fusaiolă de tip 1D (Nr. cat. 19/Pl. 19) și „,capăt de băţ” de tip I (Nr. cat. 18/P1. 18). Din suprafața locuită SL2 provin o fusaiolă de tip 6C ( Nr. cat. 12/Pl. 12) și un „capăt de băț” de tip 2D (Nr. cat. 13/ P1.13). Din cele trei greutăţi doar două au fost descoperite în context, complexul 230, o groapă de resturi menajere (Nr. cat. 22/P1 22 și Nr. cat. 23/Pl. 23).

Dacă punem cap la cap această analiză pe baza clasei de mărime, caracterelor morfologice, dar și al contextului descoperirii putem observa că în trei din cele patru locuințe au fost descoperite, în asociere, atât „,capete de băț’, cât 
și fusaiole. Un alt fapt care reține atenția este apropierea de dimensiuni dintre „,capetele de băț” și fusaiole. Astfel de asocieri avem în L1 (Nr. cat. 10: Dmax. $=3,8 \mathrm{~cm}$, Dmin. $=2,1 \mathrm{~cm}, \mathrm{~h}=2,3 \mathrm{~cm}, \mathrm{G}=34,80 \mathrm{~g}$, Dperf. $=0,8 \mathrm{~cm}$ şi Nr. cat. 20: Dmax. $=4,8 \mathrm{~cm}, \mathrm{~h}=1,9 \mathrm{~cm}, \mathrm{G}=37,93 \mathrm{~g}$, Dperf. $=0,9 \mathrm{~cm})$ şi în SL $2(\mathrm{Nr}$. Catalog 13: Dmax. $=3$ $\mathrm{cm}$, Dmin. $=2,1 \mathrm{~cm}, \mathrm{~h}=3,1 \mathrm{~cm}, \mathrm{G}=24,15 \mathrm{~g}$, Dperf. $=0,8 \mathrm{~cm}$ şi Nr. cat. 12: Dmax. $=3,8 \mathrm{~cm}$, Dmin. $=2,5 \mathrm{~cm}, \mathrm{~h}$ $=2,1 \mathrm{~cm}, \mathrm{G}=30,62 \mathrm{~g}$, Dperf. =0,8 cm). Din nefericire numărul redus de materiale de acest tip publicate și lipsa unor analize de tipul demersului nostru împiedică formularea unor ipoteze concludente asupra tipului de relație dintre fusaiole și ,capetele de băț”.

\section{Concluzii}

În stadiul actual al cercetărilor (așezarea nu a fost cercetată exhaustiv, suprafața afectată de proiect fiind de 4100 metri pătrați din cei aproximativ 18000 metri pătraţi ai sitului), în cazul comunităților preistorice de la Hurezani putem observa o majoritate deținută de fusaiolele și „,capetele de băț” mici și medii, cu mase scăzute şi forme rotunjite (discoidale și bitronconice). Astfel, putem afirma că acestea produceau fibre subțiri de dimensiuni mici, cu ajutorul cărora produceau țesături de o calitate bună, cu un număr mare de fire pe centimetru pătrat.

Descoperirile cunoscute de fusaiole din mediul Verbicioara sunt relaţiv puține ca număr. Cele mai multe se concentrau în apropierea Dunării, în siturile de la Rogova, Orevița Mare, Ostrovul Mare, Verbicioara ${ }^{21}$, etc. Acest fapt a creat imaginea că meșteșugul torsului era o activitate care se desfășura mai ales în zona bazinului inferior al Jiului și în zona Cazanelor Dunăriii ${ }^{22}$. Cu toate acestea descoperiri de fusaiole au mai apărut și în zona subcarpatică, ca de exemplu la Ceplea ${ }^{23}$. Considerăm că aceste concluzii sunt tributare doar unui stadiu al cercetării, strâns legat de suprafața cercetată, și nu de o predilecție a unor comunităţi pentru anumite activităţi economice. Legat de o posibilă legătură între tipul de fusiolă şi încadrarea cronologică şi culturală considerăm că acest tip de materiale are o relevanță redusă pentru astfel de încadrări. Astfel, în situația noastră, avem fusaiole care deși au fost descoperite în contexte Verbicioara IV își găsesc analogii în situri încadrate cultural Verbicioara I (Rogova) sau Verbicioara III (Orevița Mare, Ceplea). De altfel tipuri asemănătoare de artefacte depășesc granițele culturale și cronologice, ele fiind descoperite și în contexte Glina, de exemplu². Credem însă că există o legătură importantă între forma, dimensiunea și greutatea fusaiolelor și tipul de țesături create. Însă pentru a realiza o înseriere relevantă este nevoie de analiza tipologico-morfologică a mult mai multor obiecte de acest tip și de pe mai multe situri.

În legătură cu „,capetele de băț” s-au emis mai multe ipoteze legate de folosirea $\operatorname{lor}^{25}$. Un fapt care este admis de o mare parte a cercetătorilor este acela că aceste obiecte sunt folosite împreună cu o tijă de lemn ${ }^{26}$. Lipsa unei perforații totale face ca acestea să nu fie denumite fusaiole ${ }^{27}$. Totuși, dacă se are în vedere forma unui fus contemporan, se poate observa asemănarea dintre capătul tronconic al acestuia (capătul de jos) și forma acestor „,capete de băț”. Un alt argument al folosirii acestora la tors, din punctul nostru de vedere, este greutatea asemănătoare dintre fusaiole şi „,capetele de băț” dar și descoperirea ambelor tipuri de obiecte în contexte comune. Capacitatea acestor obiecte de a îndeplini rolul de ,volantă” pe care îl îndeplinește o fusaiolă se poate demonstra sau infirma prin arheologie experimentală

În concluzie, putem afirma existența meșteșugului producerii și prelucrării textilelor în cadrul comunităţilor preistorice din situl de la Hurezani, com. Hurezani, jud. Gorj. Deşi numărul artefactelor destinate torsului și țesutului este relativ mic, cel puțin în stadiul actual al cercetărilor, informațiile obținute sunt promițătoare și ajută la completarea datelor privind această activitate casnică în spațiul și perioada de timp menționată.

\footnotetext{
${ }_{21}$ Crăciunescu 2004.

22 Prisecaru 2009, 130.

23 Calotoiu Hortopan 2008.

4 Schuster 1997.

25 Schuster, Tuțulescu, Negru 2014, 87-91.

26 Marc 2012, 93.

27 Mazare 2012, 103-104.
} 


\section{BIBLIOGRAFIE}

Băjenaru 2014

Berciu, Comșa, PopescuIalomița 1951

Berciu, Comşa, PopescuIalomița 1952

Berciu 1961

Calotoiu, 2002,

Calotoiu, Hortopan, 2008

Colțeanu et al. 2020a

Colțeanu et al. 2020b

Crăciunescu, 2004

Marc 2012

Marinoiu et al. 2018

Mazăre 2012

Mårtensson et al. 2009

Prisecaru, 2009

Prisecaru 2014

Rustoiu 1995

Schuster1997

Schuster, Tuțulescu, Negru 2014

Ștefan 2005
Băjenaru, R., Sfârșitul bronzului timpuriu în regiunea dintre Carpați și Dunăre, Editura Argonaut, Cluj, 2014.

Berciu, D., Comșa, E., Popescu-Ialomița, S., Şantierul arheologic VerbicioaraDolj, SCIV, II, 1, 1951, 229-25.

Berciu, D., Comșa, E., Popescu-Ialomița, S., Şantierul Verbicioara, SCIV, III, 1952, 141-189.

Berciu, D., Die Verbicioara-Kultur. Vorbericht über eine neue, in Rumänien entdeckte bronzezeitliche Kultur, Dacia N.S., V, 1961, 123-161.

Calotoiu, Gh., Prima epocă a fierului în Nordul Olteniei, Editura „Alexandru Ștefulescu", Târgu Jiu, 2002.

Calotoiu, Gh., Hotopan, D., Cercetări arheologice recente specifice culturii Verbicioara în județul Gorj, Drobeta, XVIII, 2008, 65-86.

Colțeanu, P., Marinoiu, V., Prisecaru, D., Drob, S., Drob, A., Gheorghiu, L., Cercetări arheologice de diagnostic intruziv din anul 2018 - „Instalare conductă transport gaze naturale - BRUA" Lot 2, jud. Vâlcea și Gorj, Litua. Studii și Cercetări, XXII, 2020, 75-132.

Colțeanu, P., Marinoiu, V., Prisecaru, D., Heroiu, A., Drob, S., Gheorghe, O., Drob, A., Gheorghiu, L., Cercetări arheologice preventive din zona Hurezani- Căpreni, județul Gorj, desfăşurate în anul 2018, Litua. Studii și Cercetări. XXII, 2020, 133-162.

Crăciunescu, G., Cultura Verbicioara în jumătatea Vestică a Olteniei, S Bibliotheca Thracologica, XLI, Editura MJM, Craiova, 2004.

Marc, A., Consideraţii cu privire la „capetele de băţ” din cultura Wietenberg, Sargetia, XXXIX, 2012, 91-100.

Marinoiu, V., Colțeanu, P., Drob, S., Drob, A., Raport de diagnostic arheologic intruziv pentru proiectul „Instalare conductă gaz sondă Totea 4461 - Conectare la Parcul 4540 Hurezani”, 2018, mss.

Mazăre, P., Definirea și clasificarea artefactelor preistorice destinate torsului: fusaiolele, Terra Sebus, 4, 2012, 102-131.

Mårtensson, L., Nosch, M.-L., Andersson Strand, E., Shape of things: understanding a loom weight, Oxford Journal of Archaeology, 28(4), 2009, 373-398.

Prisecaru, D., Meșteșuguri casnice în epoca bronzului pe teritoriul României,. Prelucrarea materiilor textile, Corviniana XIII, 2009, 119-156.

Prisecaru, D., Prelucrarea fibrelor și textilelor în epoca bronzului în spațiul estcarpatic al României, Teză de doctorat, Iași, 2014.

Rustoiu, G., Tipologia „,capetelor de băț” aparținând culturilor bronzului mijlociu din România, BCȘS, 1, 1995, 61-72.

Schuster, C.F, Perioada timpurie a epocii bronzului în bazinele Argeșului și Ialomiței Superioare, Bibliotheca Thracologica, XX, București, 1997.

Schuster, C., Tuțulescu, I. Negru, M., Despre „capetele de băț” din epoca bronzului din sudul României. Erwägungen zu den ,stockknäufen” der bronzezeit im süden Rumäniens, Istros, XX, 2014, 79-115.

Ștefan, C., Cultura Verbicioara. Câteva observații, Argesis, XIV, 2005, 89-100. 


\section{LIST OF ILLUSTRATIONS}

Figure 1. Bitruncated spindle-whorl. Figure 2. Bitruncated spindle-whorl. Figure 3. Bitruncated spindle-whorl. Figure 4. "Stick-head", type IVa.

Figure 5. Cylindrical spindle-whorl. Figure 6. Cylindrical spindle-whorl. Figure 7. Bitruncated spindle-whorl. Figure 8. Bitruncated spindle-whorl. Figure 9. Bitruncated spindle-whorl. Figure 10. "Stick-head", type IId. Figure 11. Cylindrical loom-weight. Figure 12. Bitruncated spindle-whorl. Figure 13. "Stick-head", type IIc.

Figure 14. Cylindrical spindle-whorl.

Figure 15. Bitruncated spindle-whorl. Figure 16. "Stick-head", type IIc.

Figure 17. Truncated spindle-whorl. Figure 18. "Stick-head", type I.

Figure 19. Cylindrical spindle-whorl. Figure 20. Cylindrical spindle-whorl. Figure 21. Cylindrical spindle-whorl. Figure 22. Cylindrical loom-weight. Figure 23. Cylindrical loom-weight.

Plate 1. Aerial photography, Site 2, Hurezani.

Plate 2. Ortophotoplan of Site 2, Hurezani.

Plate 3. General layout of archaeological excavation, Site 2, Hurezani.

OANA GHEORGHE, Universitatea „Alexandru Ioan Cuza” din Iași, gheorghe.oana@yahoo.com

PETRE COLȚEANU, Universitatea „Alexandru Ioan Cuza” din Iași, petrecolteanu@gmail.com 